\title{
Determinants of disability development in patients with multiple sclerosis
}

\author{
Determinantes do desenvolvimento de deficiência em pacientes com esclerose múltipla
}

Fatma KARA', Mehmet Fatih GÖL', Cavit BOZ'

\begin{abstract}
Background: Multiple sclerosis (MS) is one of the most common chronic neurological diseases affecting the central nervous system in young adults. Objective: To investigate demographic and clinical factors that are effective in the development of irreversible disability from the onset of MS, and to identify factors that affect the transformation from the relapse-remitting MS (RRMS) phase to the progressive MS (PMS) phase. Methods: Retrospective study on 741 patients who were diagnosed with RRMS and PMS according to the McDonald criteria, and were enrolled into the Turkish MS database of the Department of Neurology MS Polyclinic, at the Faculty of Medicine, Karadeniz Technical University, in Trabzon, Turkey. Kaplan-Meier analysis was used to evaluate the time taken to reach EDSS 4 and EDSS 6 from the onset of disease, and the time taken between EDSS 4 and EDSS 6. Results: Age of onset $>40$ years; having polysymptomatic-type onset, pyramidal or bladder-intestinal system-related first episode; $\geq 7$ episodes in the first 5 years; and $<2$ years between the first two episodes were found to be effective for MS patients to reach EDSS 4 and EDSS 6 . The demographic and clinical parameters that were effective for progression from EDSS 4 to EDSS 6 were: pyramidal or bladder-intestinal system-related first episode; 4-6 episodes in the first 5 years; $>2$ years until start of first treatment; and smoking. Conclusions: Our findings reveal important characteristics of MS patients in our region. However, the associations between these parameters and MS pathophysiology remain to be elucidated.
\end{abstract}

Keywords: Multiple Sclerosis; Epidemiology; Therapy.

\section{RESUMO}

Introdução: A esclerose múltipla (EM), uma das doenças neurológicas crônicas mais comuns, afeta o sistema nervoso central em jovens adultos. Objetivo: Investigar fatores demográficos e clínicos que são efetivos no desenvolvimento de deficiência irreversível, desde o início da EM, e identificar fatores que afetam a transformação da fase de EM recorrente-remitente (EMRR) para a fase de EM secundária progressiva (EMSP). Métodos: Estudo retrospectivo de 741 pacientes que foram diagnosticados com EMRR e EMSP, de acordo com os critérios de McDonald, e inscritos no banco de dados turco MSBase, do Departamento de Neurologia da MS Polyclinic, da Universidade Técnica de Karadeniz, Turquia. Análise de Kaplan-Meier foi usada para avaliar o tempo para alcançar EDSS 4 e EDSS 6 , desde o início da doença e o tempo entre EDSS 4 e EDSS 6. Resultados: Idade de início $>40$ anos, início do tipo polissintomático, primeiro ataque relacionado ao sistema piramidal ou bexiga-intestinal, $\geq 7$ recaídas nos primeiros 5 anos e $<2$ anos entre os dois primeiros ataques foram considerados eficazes em pacientes com EM que atingiram EDSS 4 e EDSS 6. Parâmetros demográficos e clínicos que foram efetivos no progresso de EDSS 4 para EDSS 6: primeiro ataque relacionado ao sistema piramidal ou bexiga-intestinal, 4-6 recaídas nos primeiros 5 anos, $>2$ anos até o início do primeiro tratamento e tabagismo. Conclusão: Estudo revelou características importantes dos pacientes com EM em nossa região. No entanto, as associações entre esses parâmetros e a fisiopatologia da EM ainda precisam ser elucidadas.

Palavras-chave: Esclerose Múltipla; Epidemiologia; Terapia.

\section{INTRODUCTION}

Multiple sclerosis (MS) is one of the most common chronic neurological diseases affecting the central nervous system (CNS) in young adults. Its frequency is higher among females ${ }^{1}$. MS progresses with inflammatory demyelination and subsequent axonal loss, which causes a wide range of unpredictable functional disabilities that are associated with the CNS region(s) affected ${ }^{2,3}$. It was reported in 2013 that around 2.3 million people suffer from MS on a global scale ${ }^{4}$.

There are three types of MS. The first and the most common type is relapsing-remitting multiple sclerosis (RRMS), which is characterised by relapses of new or increasing neurological symptoms that are followed by periods of partial

${ }^{1}$ Karadeniz Technical University, Faculty of Medicine, Department of Neurology, Trabzon, Turkey.

Fatma KARA (D) https://orcid.org/0000-0002-4675-0689; Mehmet Fatih GÖL (D) https://orcid.org/0000-0001-7773-641X;

Cavit BOZ (iD) https://orcid.org/0000-0003-0956-3304

Correspondence: Mehmet Fatih Göl; E-mail: m-fatih-gol@hotmail.com.

Conflict of interest: There is no conflict of interest to declare.

Authors' contributions: FK: performed data collection. MFG, FK: data analysis and interpretation. FK: primary author. CB: conceived the ideas. MFG, FK and CB: provided revisions to scientific consent of manuscript. MFG, FK and CB: principal investigators.

Received on July 15, 2020; Received in its final form on August 22, 2020; Accepted on September 07, 2020. 
or complete recovery. The secondary progressive (SPMS) course develops in RRMS patients around 15-20 years after onset. The third type is primary progressive multiple sclerosis (PPMS), which shows steady progression from the onset for at least 6 months or more without attacks 5 .

Clinical variability during the onset of MS may provide important prognostic clues about the progression of the disease to the progressive stage. Factors associated with a good prognosis in MS include early onset, female sex, initial symptoms consisting of sensory symptoms or optic neuritis, cases in which the initial symptom affects only one CNS region, having less disability at 5 years after onset, better recovery after the first episode, longer duration between first and second episode, low number of episodes during the first five years and a long time until the Expanded Disability Status Scale (EDSS) score exceeds 3 points. On the other hand, the following factors are considered to suggest poor prognosis: male sex, advanced age, onset with motor-cerebellar-spinal cord or bladder-intestinal tract symptoms, incomplete recovery after the first episode, high relapse rate in the first two years, severe disability at 5 years after onset, a short time until EDSS score exceeds 3 points and a short time between the first and second episodes ${ }^{6,7}$. Because the disease is unpredictable in nature and the factors affecting prognosis vary from region to region ${ }^{8,910}$, determining the characteristics of disease progression and factors that contribute to disabilities are of high importance for clinical management.

In this study, we aimed to determine the demographic and clinical factors that are effective for development of irreversible disability from the onset of disease, and to identify factors that affect the transformation from the RRMS phase to the secondary progressive MS (SPMS) phase.

\section{METHODS}

\section{Patients}

This was a retrospective study on 741 patients who were diagnosed with RRMS and PMS in accordance with the McDonald criteria ${ }^{11}$. This study analyzed a cohort of Turkish people: demographic and clinical data were collected from the medical records of the Turkish MS Registry at Farabi Hospital, Faculty of Medicine, Karadeniz Technical University, in Trabzon, Turkey. The patients were followed up on a regular basis, with at least one visit every 3-4 months, and the patients were also examined when they came back to the hospital during periods of active complaints. Approval for the study was obtained from Karadeniz Technical University Faculty of Medicine Ethics Council.

\section{Inclusion criteria}

- Patients diagnosed with RRMS and SPMS in accordance with the McDonald 2010 criteria.

- Signing the consent form and agreeing to participate and continue in the study.

\section{Exclusion criteria}

- Diagnoses of PPMS and progressive relapsing MS (PRMS) (those with progressive-type onset).

- Diagnoses of any other neurological or psychological disease.

- Not signing the consent form.

\section{Study design}

Forms prepared by the researchers were used to determine the clinical features of the disease and the sociodemographic characteristics of the patients. The following were recorded on the patient preliminary information form: patient's name and sex, disease history, family history, patient's complaints on admission, date of disease onset, number of episodes, date and time of episodes, history of episodes, episode treatments, medications used in MS treatment, treatment duration, other physical diseases and medications used, EDSS score, diagnostic tools and history of drug and substance use. These forms were filled out when the patient first sought care, and the forms were also updated at the times of patient follow-ups.

The following parameters were evaluated for associations with disease progression: age at onset, sex, type of onset (determined as monosymptomatic or polysymptomatic),type of first episode, number of episodes in the first five years after the onset of the disease, length of time between the first and second episodes, time of starting immunomodulator or immunosuppressive treatments that affect disease progression, smoking (and number of cigarettes smoked per day), presence of EDSS 4 (limitation of walking without restriction) and EDSS 6 (walking with one-sided support), and the time taken to reach specific degrees of disability, such as progression from EDSS 4 to EDSS 6.

In this study, the patients were classified according to the first attack types, into five categories: sensory, visual, pyramidal, brainstem-cerebellar and bladder-intestinal. They were classified based on their age at onset of the disease, into the following three categories: $<18,18-40$ or $>40$ years. They were classified based on the number of relapses in the first five years, into the following three groups: $1-3,4-6$ and $\geq 7$ relapses. The patients were divided into three groups according to the time interval between the first two attacks $(<2,2-5$ and $>5$ years) and they were also divided into two groups according to the starting time of treatment ( $\leq 2$ years and $>2$ years).

In MS, an episode (a period of worsening) is defined as a period wherein new symptoms develop or existing symptoms are exacerbated, or a period in which new neurological findings lasting for at least 24 hours (often ending with partial or complete recovery) are observed. Symptoms occurring within one month are considered as part of the same episode. The progressive phase is defined as continuous worsening of symptoms and indications for at least 6 months, with or without the occurrence of episodes, that causes an irreversible increase of at least 1.0 point in EDSS score when it was 
previously $\leq 5.5$ or 0.5 point when it was $>5.5$ (increases in EDSS score in the period related to relapses and independent from corticosteroid treatment response were ruled out) ${ }^{4,6}$.

\section{Statistical analysis}

The data obtained from the study were transferred to electronic media and analyzed using the SPSS 20.0 statistical software package. In addition to descriptive statistical methods (mean, standard deviation, median, frequency, ratio, minimum and maximum), quantitative data were analyzed by means of statistical tests. Chi-square analysis was used to evaluate whether there was any difference between two or more groups, whether there was any correlation between the two variables and the degree of homogeneity between groups. In the chi-square analysis used in our study, the endpoints were defined as reaching EDSS 4, reaching EDSS 6, progression from EDSS 4 to EDSS 6, and reaching the secondary progressive phase of the disease. Kaplan-Meier analysis was also used to evaluate the times taken to reach EDSS 4 and EDSS 6 from the onset of disease, and the length of time between EDSS 4 and EDSS 6. The statistical significance level was determined as $p<0.05$ in all analyses.

\section{RESULTS}

\section{Demographic and clinical characteristics of multiple sclerosis patients}

Out of the 926 MS patients registered in the Turkish MS database, 741 patients were included in this study and 185 MS patients were excluded. These were excluded because of their progressive onset, missing EDSS scores or irregular follow-up. There were 235 patients with follow-ups shorter than 5 years, 450 MS patients with follow-ups shorter than 10 years and 291 MS patients with follow ups of more than 10 years. The demographic and clinical characteristics of the MS patients are shown in Table 1.

Among the 741 MS patients who met the inclusion criteria, $65.6 \%(n=486)$ were female and $34.4 \%(n=255)$ were male. The female/male ratio was 1.9. Among these patients, $87 \%$ $(\mathrm{n}=645)$ had a diagnosis of RRMS and 13\% ( $\mathrm{n}=96)$ had a diagnosis of PMS (Table 1).

Evaluation of the descriptive statistics on the demographic and clinical characteristics of the patients with RRMS and PMS showed that low education level $(\mathrm{p}<0.001)$, being single $(\mathrm{p}<0.001)$, higher age $(\mathrm{p}<0.001)$, polysymptomatic onset $(\mathrm{p}<0.001)$, having an initial episode with pyramidal or bladder-intestinal symptoms $(\mathrm{p}<0.001)$, higher number of episodes in first 5 years $(\mathrm{p}<0.001)$, short time period between the first two episodes $(p=0.046)$ and longer time period until the start of the first treatment $(p<0.001)$ were associated with worse clinical progress. The results from the chi-square analysis on the demographic and clinical characteristics of MS patients are shown in Table 2.
Table 1. Demographic and clinical features of multiple sclerosis patients.

\begin{tabular}{|c|c|c|c|}
\hline Mean \pm SD or $n / \%)$ & RRMS $(n=645)$ & PMS $(n=96)$ & $p$-value \\
\hline \multicolumn{4}{|l|}{ Sex } \\
\hline Male & $224(34.7 \%)$ & $31(32.3 \%)$ & \multirow{2}{*}{0.639} \\
\hline Female & $421(65.3 \%)$ & $65(67.7 \%)$ & \\
\hline \multicolumn{4}{|l|}{ Educational level } \\
\hline Illiterate & $12(2 \%)$ & $5(5.7 \%)$ & \multirow{4}{*}{$<0.001^{\star}$} \\
\hline Primary school & $256(41.6 \%)$ & $60(69.0 \%)$ & \\
\hline High school & $161(26.2 \%)$ & $14(16.1 \%)$ & \\
\hline University & $186(30.2 \%)$ & $8(9.2 \%)$ & \\
\hline \multicolumn{4}{|l|}{ Marital status } \\
\hline Single & $162(26.2 \%)$ & $6(68 \%)$ & \multirow{3}{*}{$<0.001 *$} \\
\hline Married & 451 (72.9\%) & $79(89.8 \%)$ & \\
\hline Divorced & $6(1 \%)$ & $3(3.4 \%)$ & \\
\hline Age (years) & $39.34( \pm 10.67)$ & $50.04( \pm 8.64)$ & $<0.001^{*}$ \\
\hline Age at onset (years) & $30.03( \pm 10.11)$ & $31.56( \pm 10.31)$ & 0.168 \\
\hline $\begin{array}{l}\text { Duration of disease } \\
\text { (years) }\end{array}$ & $7.65( \pm 7)$ & $8.32( \pm 6.11)$ & 0.073 \\
\hline \multicolumn{4}{|l|}{ Disease onset } \\
\hline Monosymptomatic & $591(91.6 \%)$ & $70(72.9 \%)$ & \multirow{2}{*}{$<0.001^{*}$} \\
\hline Polysymptomatic & $54(8.4 \%)$ & $26(27.1 \%)$ & \\
\hline \multicolumn{4}{|l|}{ First attack type } \\
\hline Visual & $160(24.8 \%)$ & $13(13.5 \%)$ & \multirow{5}{*}{$<0.001^{*}$} \\
\hline Sensory & 147 (22.8\%) & $4(4.2 \%)$ & \\
\hline Pyramidal & $176(27.3 \%)$ & $56(58.3 \%)$ & \\
\hline $\begin{array}{l}\text { Brainstem- } \\
\text { cerebellar }\end{array}$ & $155(24 \%)$ & $21(21.9 \%)$ & \\
\hline Bladder-intestinal & $7(1.1 \%)$ & $2(2.1 \%)$ & \\
\hline $\begin{array}{l}\text { Number of attacks in } \\
5 \text { years }\end{array}$ & $2.79( \pm 1.52)$ & $5.18( \pm 1.77)$ & $<0.001^{\star}$ \\
\hline $\begin{array}{l}\text { Time between first } \\
\text { two attacks (months) }\end{array}$ & $33( \pm 45)$ & $25.5( \pm 38.7)$ & $0.046^{\star}$ \\
\hline $\begin{array}{l}\text { Treatment start time } \\
\text { (months) }\end{array}$ & $46.2( \pm 64.8)$ & $94.4( \pm 89)$ & $<0.001^{\star}$ \\
\hline \multicolumn{4}{|l|}{ Smoking } \\
\hline Yes & $172(90.1 \%)$ & $19(9.9 \%)$ & \multirow{2}{*}{0.991} \\
\hline No & $314(90.5 \%)$ & $33(9.5 \%)$ & \\
\hline \multicolumn{4}{|c|}{ Number of cigarettes per day } \\
\hline $1-10$ & $44(32.6 \%)$ & $6(50 \%)$ & \multirow{2}{*}{0.340} \\
\hline$\geq 10$ & $91(67.4 \%)$ & $6(50 \%)$ & \\
\hline \multicolumn{4}{|c|}{ Types of disease-modifying treatment } \\
\hline \multicolumn{4}{|c|}{ First-line therapies } \\
\hline Interferon beta-1a & $261(40.5 \%)$ & $40(41.7 \%)$ & \\
\hline Interferon beta-1b & $120(18.6 \%)$ & $21(21.9 \%)$ & \\
\hline Glatiramer acetate & $129(20 \%)$ & $20(20.8 \%)$ & \\
\hline \multicolumn{4}{|l|}{ Second-line therapies } \\
\hline Azathioprine & $3(0.4 \%)$ & $10(10.4 \%)$ & $>0.05$ \\
\hline Fingolimod & $34(5.3 \%)$ & - & \\
\hline Teriflunomide & $23(3.6 \%)$ & - & \\
\hline Methotrexate & - & $2(2.1 \%)$ & \\
\hline Mitoxantrone & - & $2(2.1 \%)$ & \\
\hline Natalizumab & - & $1(1 \%)$ & \\
\hline \multicolumn{4}{|l|}{ Cyclophosphamide } \\
\hline $\begin{array}{l}\text { Not receiving any } \\
\text { treatment }\end{array}$ & $74(11.5 \%)$ & - & \\
\hline
\end{tabular}

RRMS: relapse-remitting multiple sclerosis. 
Table 2. Distribution of progression among multiple sclerosis patients.

\begin{tabular}{|c|c|c|c|c|c|c|c|c|c|}
\hline & Total & EDSS 4 & $p$-value & EDSS 6 & $p$-value & $\begin{array}{c}\text { Progressive } \\
\text { phase }\end{array}$ & $p$-value & EDSS 4-6 & $\mathrm{p}$-value \\
\hline \multicolumn{10}{|l|}{ Sex } \\
\hline Male & 486 & $143(29.4 \%)$ & \multirow{2}{*}{0.273} & $83(17.1 \%)$ & \multirow{2}{*}{0.554} & $65(13.4 \%)$ & \multirow{2}{*}{0.639} & $77(53.8 \%)$ & \multirow{2}{*}{0.968} \\
\hline Female & 255 & $85(33.3 \%)$ & & $48(18.8 \%)$ & & $31(12.2 \%)$ & & $46(54.1 \%)$ & \\
\hline \multicolumn{10}{|l|}{ Age at onset } \\
\hline$<18$ & 59 & $21(35.6 \%)$ & \multirow{3}{*}{0.069} & $8(13.6 \%)$ & \multirow{3}{*}{0.398} & $6(10.2 \%)$ & \multirow{3}{*}{0.277} & $7(33.3 \%)$ & \multirow{3}{*}{0.102} \\
\hline $18-40$ & 560 & $160(28.6 \%)$ & & $97(17.3 \%)$ & & $69(12.3 \%)$ & & $92(57.5 \%)$ & \\
\hline$>40$ & 122 & $47(38.5 \%)$ & & $26(21.3 \%)$ & & $21(17.2 \%)$ & & $24(51.1 \%)$ & \\
\hline \multicolumn{10}{|l|}{ Disease onset } \\
\hline Monosymptomatic & 661 & $186(28.1 \%)$ & \multirow{2}{*}{$<0.001 \star$} & $101(15.3 \%)$ & \multirow{2}{*}{$<0.001 *$} & $70(10.6 \%)$ & \multirow{2}{*}{$<0.001^{\star}$} & $95(51.1 \%)$ & \multirow{2}{*}{0.097} \\
\hline Polysymptomatic & 80 & $42(52.5 \%)$ & & $30(37.5 \%)$ & & $26(32.5 \%)$ & & $28(66.7 \%)$ & \\
\hline \multicolumn{10}{|l|}{ First attack type } \\
\hline Visual & 173 & $43(24.9 \%)$ & \multirow{5}{*}{$<0.001 *$} & $22(12.7 \%)$ & \multirow{5}{*}{$<0.001^{\star}$} & $13(7.5 \%)$ & \multirow{5}{*}{$<0.001 *$} & $18(41.9 \%)$ & \multirow{5}{*}{$0.005^{\star}$} \\
\hline Brainstem-cerebellar & 176 & $48(27.3 \%)$ & & $26(14.8 \%)$ & & $21(11.9 \%)$ & & $26(54.2 \%)$ & \\
\hline Pyramidal & 232 & $112(48.3 \%)$ & & $74(31.9 \%)$ & & $56(24.1 \%)$ & & $70(62.5 \%)$ & \\
\hline Sensory & 151 & $22(14.6 \%)$ & & $6(4 \%)$ & & $4(2.6 \%)$ & & $6(27.3 \%)$ & \\
\hline Bladder-intestinal & 9 & $3(33.3 \%)$ & & $3(33.3 \%)$ & & $2(22.2 \%)$ & & $3(100 \%)$ & \\
\hline \multicolumn{10}{|c|}{ Number of attacks in 5 years } \\
\hline $1-3$ & 519 & $115(22.2 \%)$ & \multirow{3}{*}{$<0.001 *$} & $44(8.5 \%)$ & \multirow{3}{*}{$<0.001^{\star}$} & $18(\% 3.5)$ & \multirow{3}{*}{$<0.001 *$} & $39(33.9 \%)$ & \multirow{3}{*}{$<0.001^{*}$} \\
\hline $4-6$ & 174 & $84(48.3 \%)$ & & $63(36.2 \%)$ & & $55(\% 31.6)$ & & $60(71.4 \%)$ & \\
\hline$\geq 7$ & 48 & $29(60.4 \%)$ & & $24(50 \%)$ & & $23(\% 47.9)$ & & $24(82.8)$ & \\
\hline \multicolumn{10}{|c|}{ Time between first two attacks } \\
\hline$<2$ years & 428 & $136(31.8 \%)$ & \multirow{3}{*}{$0.007 *$} & $86(20.1 \%)$ & & $69(16.1)$ & & $81(59.6 \%)$ & \\
\hline $2-5$ years & 197 & $47(23.9 \%)$ & & $23(11.7 \%)$ & $0.029 *$ & $18(8.5 \%)$ & $0.017 *$ & $20(42.6 \%)$ & 0.108 \\
\hline$>5$ years & 107 & $44(41.1 \%)$ & & $22(20.6 \%)$ & & $9(9.8 \%)$ & & $22(50 \%)$ & \\
\hline Time of treatment after $\mathrm{d}$ & gnosis & & & & & & & & \\
\hline$\leq 2$ years & 320 & $66(20.6 \%)$ & $<\cap \cap \cap 1 *$ & $29(9.1 \%)$ & < & $19(5.9 \%)$ & ८ คค 1* & $27(40.9 \%)$ & ( \\
\hline$>2$ years & 340 & $150(44.1 \%)$ & 50.001 & $96(28.2 \%)$ & 8.001 & $69(20.3 \%)$ & 10.001 & $90(60 \%)$ & .000 \\
\hline Smoking & & & & & & & & & \\
\hline Yes & 191 & $56(29.3 \%)$ & ? ?ח9 0 & $34(17.8 \%)$ & $0<0$ & $19(9.9 \%)$ & - & $32(57.1 \%)$ & ( \\
\hline No & 347 & $100(28.8 \%)$ & & $53(15.3 \%)$ & & $33(9.5 \%)$ & ז & $47(47 \%)$ & (1.20. \\
\hline Number of cigarettes per & & & & & & & & & \\
\hline $1-10$ & 50 & $13(26 \%)$ & 10 (10 & $8(16 \%)$ & 0723 & $6(12 \%)$ & $03 / 0$ & $7(53.8 \%)$ & 0 on \\
\hline$\geq 10$ & 97 & $24(24.7 \%)$ & 1.000 & $12(12.4 \%)$ & $0.1 \angle 3$ & $6(6.2 \%)$ & 0.340 & $11(45.8 \%)$ & 0.904 \\
\hline
\end{tabular}

EDSS: Expanded Disability Status Scale.

The results from Kaplan-Meier analysis on demographic and clinical parameters affecting the progression and development of MS patients are shown in Table 3. It was observed that the demographic and clinical parameters that were effective regarding the time taken to reach EDSS 4 and EDSS 6 were similar. These parameters were as follows: age at onset $>40$ years; having polysymptomatic-type onset, pyramidal or bladderintestinal system-related first attack; $\geq 7$ relapses in the first 5 years; and $<2$ years between the first two attacks. The demographic and clinical parameters that were effective regarding the progress from EDSS 4 to EDSS 6 were: pyramidal or bladder-intestinal system-related first attack; $>3$ relapses in the first 5 years; > 2 years until initiation of first treatment; and smoking.

\section{DISCUSSION}

MS is the most common of the diseases that develop due to inflammatory demyelinating events in the CNS. It is a chronic disease that progresses with neuroinflammation 
Table 3. Demographic and clinical features affecting progression among multiple sclerosis patients.

\begin{tabular}{|c|c|c|c|c|c|c|c|c|c|c|}
\hline & \multirow{2}{*}{ Total } & \multicolumn{3}{|c|}{$\begin{array}{l}\text { Time taken to } \\
\text { reach EDSS } 4\end{array}$} & \multicolumn{3}{|c|}{$\begin{array}{l}\text { Time taken to } \\
\text { reach EDSS } 6\end{array}$} & \multicolumn{3}{|c|}{$\begin{array}{l}\text { Time taken to go from } \\
\text { EDSS } 4 \text { to EDSS } 6\end{array}$} \\
\hline & & Median & $95 \% \mathrm{Cl}$ & $p$-value & Median & $95 \% \mathrm{Cl}$ & $p$-value & Median & $95 \% \mathrm{Cl}$ & $p$-value \\
\hline General & 741 & 15.4 & $12.9-17.9$ & & 21.9 & $18.8-25.0$ & & 3.0 & $2.5-3.5$ & \\
\hline \multicolumn{11}{|l|}{ Sex } \\
\hline Female & 486 & 15.4 & $12.9-17.9$ & \multirow{2}{*}{0.370} & 20.2 & $15.8-24.6$ & \multirow{2}{*}{0.595} & 3.0 & $2.4-3.7$ & \multirow{2}{*}{0.713} \\
\hline Male & 255 & 14.2 & $8.6-19.9$ & & 23.5 & $15.8-31.1$ & & 2.8 & $1.9-3.7$ & \\
\hline \multicolumn{11}{|l|}{ Age at onset } \\
\hline$<18$ & 59 & 17.8 & $8.2-27.5$ & \multirow{3}{*}{$<0.001 *$} & 25.9 & & \multirow{3}{*}{$0.003^{\star}$} & 5.6 & $0-11.9$ & \multirow{3}{*}{0.110} \\
\hline $18-40$ & 560 & 16.3 & $12.9-19.7$ & & 20.2 & $16.3-24.1$ & & 2.8 & $2.0-3.5$ & \\
\hline$>40$ & 122 & 10.3 & $8.7-11.8$ & & 15.6 & $10.5-20.6$ & & 3.3 & $2.6-3.9$ & \\
\hline \multicolumn{11}{|l|}{ Disease onset } \\
\hline Monosymptomatic & 661 & 15.8 & $13.3-18.4$ & \multirow{2}{*}{$0.002^{*}$} & 23.5 & $19.0-27.9$ & \multirow{2}{*}{$0.001 *$} & 3.0 & $2.4-3.7$ & \multirow{2}{*}{0.285} \\
\hline Polysymptomatic & 80 & 9.1 & $7.0-11.2$ & & 13.0 & $10.9-15.1$ & & 2.9 & $1.7-4.0$ & \\
\hline \multicolumn{11}{|l|}{ First attack type } \\
\hline Visual & 173 & 19.7 & $17.8-21.6$ & \multirow{5}{*}{$<0.001 *$} & 24.3 & $21.2-27.4$ & \multirow{5}{*}{$<0.001 *$} & 3.0 & $1.5-4.6$ & \multirow{5}{*}{$0.013 *$} \\
\hline Brainstem-cerebellar & 176 & 13.5 & $7.9-19.2$ & & 23.1 & $13.4-32.8$ & & 2.2 & $1.3-3.1$ & \\
\hline Pyramidal & 232 & 10.2 & $8.3-12.0$ & & 16.4 & $13-19.8$ & & 3.4 & $2.4-4.4$ & \\
\hline Sensory & 151 & 42.2 & & & & & & & & \\
\hline Bladder-intestinal & 9 & 8.2 & $0-18.5$ & & 10.3 & $2.7-17.8$ & & 2.0 & $1.8-2.2$ & \\
\hline \multicolumn{11}{|c|}{ Number of attacks in 5 years } \\
\hline $1-3$ & 519 & 19.7 & $16.6-22.9$ & \multirow{3}{*}{$<0.001^{\star}$} & 28.7 & $23.9-33.5$ & \multirow{3}{*}{$<0.001 *$} & 5.3 & $3.2-7.3$ & \multirow{3}{*}{$0.001 *$} \\
\hline $4-6$ & 174 & 10.8 & $8.2-13.4$ & & 15.9 & $12.4-19.5$ & & 2.8 & $2.5-3.1$ & \\
\hline$\geq 7$ & 48 & 5.9 & $1.2-10.7$ & & 11.4 & $9.1-13.6$ & & 3.2 & $1.8-2.5$ & \\
\hline \multicolumn{11}{|c|}{ Time between first two attacks } \\
\hline$<2$ years & 428 & 11.3 & $9.3-13.2$ & \multirow{3}{*}{$<0.001^{\star}$} & 16.5 & $12.9-20.1$ & & 2.9 & $2.3-3.5$ & \\
\hline $2-5$ years & 197 & 17.1 & $11.9-22.3$ & & 20.2 & $18.4-22.0$ & $<0.001^{\star}$ & 3.0 & $1.0-5.3$ & 0.453 \\
\hline$>5$ years & 107 & 20.7 & $16.8-24.7$ & & 28.7 & $25.4-32.0$ & & 3.5 & $1.0-6.1$ & \\
\hline Time of treatment after $\mathrm{d}$ & gnosis & & & & & & & & & \\
\hline$\leq 2$ years & 320 & 14.2 & $6.2-22.2$ & 0210 & & & 0753 & 5.0 & $2.9-7.0$ & $0.015 *$ \\
\hline$>2$ years & 340 & 15.4 & $12.7-18.1$ & & 21.1 & $17.7-24.5$ & & 2.7 & $2.2-3.2$ & \\
\hline Smoking & & & & & & & & & & \\
\hline Yes & 191 & 14.2 & $7.4-21.0$ & 0846 & 21.1 & $13.5-28.7$ & 0243 & 2.6 & $1.8-3.3$ & *18* \\
\hline No & 347 & 15.5 & $12.8-18.2$ & 0.040 & 20.1 & $15.2-28.5$ & 0.243 & 4.2 & $2.3-6.1$ & $0.010^{\circ}$ \\
\hline Number of cigarettes per & & & & & & & & & & \\
\hline $1-10$ & 50 & 19.0 & $3.1-34.9$ & 0583 & & & 0200 & 2.7 & $1.0-4.8$ & 0470 \\
\hline$\geq 10$ & 97 & 15.8 & $8.4-23.3$ & & 21.1 & & 0.200 & 2.8 & $0-5.6$ & \\
\hline
\end{tabular}

EDSS: Expanded Disability Status Scale; $95 \% \mathrm{Cl}$ : 95\% confidence interval.

and neurodegeneration in the CNS and is considered to be of autoimmune origin. It involves the cortex and deep gray matter, but white matter is usually affected to a higher degree. Demyelination and axonal degeneration associated with MS lesions cause different degrees of disability development in patients.

In the current study, it was found that sex was not an effective factor for disability development. In other studies, the general impression was that the disease had worse prognosis in male patients than in female patients ${ }^{12,13,14,15}$. However, in yet other published studies, male sex was not found to be a factor associated with poor prognosis, as in our study ${ }^{16,17,18}$. In our study, the reason why the male patient group was not associated with a poor prognosis was thought to be the similar prevalence of the disease in males and females, and the exclusion of PPMS and PRMS 
patients with a progressive-type onset, which may have obscured the results.

Compared with other types of episodes, having an initial episode with bladder-intestinal system symptoms was found to be associated with shorter time to reach EDSS 4 and 6 , and faster progression from EDSS 4 to EDSS 6. Furthermore, we observed that the type of first episode had a significant effect on disability development. In the literature, four different studies showed results similar to our study, concluding that patients with a first episode related to the bladder-intestinal system were at increased risk of disability development, whereas only one study reported that sphincter symptoms had no independent effect on disability development ${ }^{19,20}$. However, different results have been obtained in other studies, and some have associated various other symptoms with MS prognosis (for better or for worse) ${ }^{17,21}$. Although these studies show that there are contradictory results in the literature, our results were similar to those of the majority of studies, and we found that having a first episode related to the bladder-intestinal system was an effective factor in the development of irreversible disability.

In our study, MS patients were divided into three age groups according to disease onset $(<18,18-40$, and over 40 years of age). From evaluating these groups, we concluded that being over 40 years old at diagnosis was a factor associated with increased disability development. Similar to our study, other studies have also found that late onset of dis-

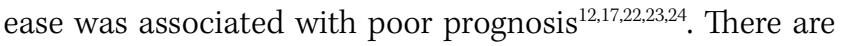
a few studies that reported different findings. For instance, in a study by Trojano et al. published in 1995, it was found that late onset was associated with good prognosis; however, the limit for advanced age was identified as 25 years in that study ${ }^{25}$. Similarly, in another published study, the age at onset of the disease was not found to be associated with poor prognosis ${ }^{18}$. Consistent with many other studies in the literature, we determined that late onset of disease was an indicator of worse clinical progress. This may be attributed to the agerelated deterioration of repair mechanisms.

Comparison of onset type showed that MS patients with polysymptomatic-type onset reached EDSS 4 and EDSS 6 significantly faster than patients with monosymptomatic-type onset. In the literature, two different studies reported results similar to ours ${ }^{22,26}$. On the other hand, polysymptomatic-type onset was found to have no effect on the prognosis of MS in several studies ${ }^{27}$. Our findings can be explained by the fact that the involvement of multiple neurological systems at the same time may be a clinical indicator of the involvement of more than one region in the CNS. Therefore, a relationship between the number of lesions and disability development may exist.

We found that patients with $\geq 7$ episodes in the first five years reached EDSS 4 and EDSS 6 in shorter times, and that their progress from EDSS 4 to EDSS 6 was faster than was seen among other patients. Similarly, in other studies, it was concluded that the number of episodes was an effective factor for disability development ${ }^{1,12,16,22,27}$. In the study by Tremlett et al., it was found that the number of episodes in the first five years had a significant effect on disease progression, but that the number of episodes over the longer term was less impor$\operatorname{tant}^{28}$. Consistent with the literature, we found that a high number of episodes in the first five years was associated with disability development.

It was found that patients with $<2$ years between the first two episodes reached EDSS 4 and EDSS 6 faster, and there was a statistically significant difference, compared with the other two groups. Consistent with our study, other studies have also shown that a short time interval between the first two episodes is indicative of worse disease progres$\operatorname{sion}^{16,17,27,29,30}$. Almost all studies in the literature suggest results similar to ours.

There was no statistically significant difference in the time taken to reach EDSS 4 and EDSS 6 between the two groups, according to the time when treatment was started, but it was observed that starting the treatment after two years shortened the progression from EDSS 4 to EDSS 6, and this difference was significant. There are studies in the literature showing that starting treatment early was not related to progression of the disease ${ }^{29,31,32}$. Similarly, in another study, receiving treatment at any time of the disease was not associated with poor prognosis ${ }^{18}$ In three different studies, it was shown that disease progression measured by the time taken to reach EDSS milestones was slower with IFN $\beta$ treatment $^{30,33,34,35}$. In another study, it was found that treatments that were effective against the course of the disease that were started during the clinical isolated syndrome stage prevented disability development ${ }^{36}$. These results suggest that treatments that are effective against the course of the disease may have partially positive effects on disability development. However, in our patient group, there were 235 patients with follow-ups shorter than 5 years, 450 MS patients with follow-ups shorter than 10 years and 291 MS patients with follow-ups of more than 10 years. The fact that the time when treatment started was not directly related to disability development can be explained by the different treatment options used by the patients, and by insufficient follow-up duration for many of our patients, which would limit the evaluation of long-term outcomes from treatments.

In our study, smoking was found to have no effect on reaching the EDSS 4 and EDSS 6 milestones, but it was found that it shortened the progression from EDSS 4 to 6, and this difference was statistically significant. Many studies investigating the relationship between smoking and MS progression have suggest that smoking causes disease progression ${ }^{37,38,39,40}$. The reason why the results from our study were partially consistent with the literature was thought to be related to the lack of smoking data in most patient records included in this study and the possibility that patients provided incomplete or incorrect information about smoking. 
In conclusion, in this study, some factors that cause worse disease progression in MS patients were identified. To summarize, these factors were: age at onset (being older than 40 years); polysymptomatic-type onset; having a first-episode type related to the bladder-intestinal system; $\geq 7$ episodes in the first 5 years; $<2$ years between the first two episodes; time until the start of treatment greater 2 years; and smoking.

\section{References}

1. Alroughani R, Akhtar S, Ahmed S, Al-Hashel J. Clinical predictors of disease progression in multiple sclerosis patients with relapsing onset in a nation-wide cohort. Int J Neurosci. 2015;125(11):831-7. https://doi.org/10.3109/00207454.2014.976641

2. Abbasi M, Nabavi SM, Fereshtehnejad SM, Ansari I, Zerafatjou N, Shayegannejad V, et al. Risk factors of Multiple sclerosis and their relation with disease severity: a cross-sectional study from Iran. Arch Iran Med. 2016 Dec;19(12):852-60.

3. Debouverie M. Gender as a prognostic factor and its impact on the incidence of multiple sclerosis in Lorraine, France.J Neurol Sci. 2009;286(1-2):14-7. https://doi.org/10.1016/j.jns.2009.07.012

4. Browne P, Chandraratna D, Angood C, Tremlett H, Baker C, Taylor BV, et al. Atlas of multiple sclerosis 2013: a growing global problem with widespread inequity. Neurology. 2014 Sep;83(11):1022-4. https://doi. org/10.1212/WNL.00000000000000768

5. Bogosian A, Morgan M, Moss-Morris R. Multiple challenges for people after transitioning to secondary progressive multiple sclerosis: a qualitative study. BMJ Open. 2019 Mar;9(3):e026421. https://doi.org/10.1136/bmjopen-2018-026421

6. Langer-Gould A, Popat RA, Huang SM, Cobb K, Fontoura P, Gould $\mathrm{MK}$, et al. Clinical and demographic predictors of long-term disability in patients with relapsing-remitting multiple sclerosis: a systematic review. Arch Neurol. 2006 Dec;63(12):1686-91. https://doi. org/10.1001/archneur.63.12.1686

7. Ontaneda D, Thompson AJ, Fox RJ, Cohen JA. Progressive multiple sclerosis: prospects for disease therapy, repair, and restoration of function. Lancet. $2017 \mathrm{Apr} ; 389(10076): 1357-66$. https://doi. org/10.1016/S0140-6736(16)31320-4

8. Rosati G. The prevalence of multiple sclerosis in the world: an update. Neurol Sci. 2001 Apr;22(2):117-39. https://doi.org/10.1007/ s100720170011

9. Debouverie M, Lebrun C, Jeannin S, Pittion-Vouyovitch S, Roederer T, Vespignani H. More severe disability of North Africans vs Europeans with multiple sclerosis in France. Neurology. 2007 Jan 2;68(1):29-32. https://doi.org/10.1212/01.wnl.0000250347.51674.d7

10. Hentati E, Ben Sassi S, Nabli F, Mabrouk T, Zouari M, Hentati F. Disability progression in multiple sclerosis: a Tunisian prospective cohort study. Neurol Sci. 2018 May;39(5):879-84. https://doi. org/10.1007/s10072-018-3295-4

11. Poser CM, Paty DW, Scheinberg L, McDonald WI, Davis FA, Ebers GC, et al. New diagnostic criteria for multiple sclerosis: guidelines for research protocols. Ann Neurol. 1983 Mar;13(3):227-31. https://doi. org/10.1002/ana.410130302

12. Confavreux C, Vukusic S, Adeleine P. Early clinical predictors and progression of irreversible disability in multiple sclerosis: an amnesic process. Brain. 2003 Apr;126(Pt 4):770-82. https://doi. org/10.1093/brain/awg081

13. Confavreux C, Vukusic S. Natural history of multiple sclerosis: a unifying concept. Brain. 2006 Mar;129(Pt 3):606-16. https://doi. org/10.1093/brain/awl007

14. Leray E, Yaouanq J, Le Page E, Coustans M, Laplaud D, Oger J, et al. Evidence for a two-stage disability progression in multiple sclerosis. Brain. 2010 Jul 133(7):1900-13. https://doi.org/10.1093/brain/awq076

15. Vukusic S, Confavreux C. Natural history of multiple sclerosis: risk factors and prognostic indicators. Curr Opin Neurol. 2007 Jun;20(3):269-74. https://doi.org/10.1097/WCO.0b013e32812583ad
16. Hampshire-Araújo F, Bergmann A, Alvarenga RMP, Vasconcelos CCF. Malignant multiple sclerosis: clinical and demographic prognostic factors. Arq Neuro-Psiquiatr. 2017 Mar;75(3):139-41. https://doi. org/10.1590/0004-282X20170010

17. Vasconcelos C, Aurenção J, Alvarenga R, Thuler L. Long-term MS secondary progression: Derivation and validation of a clinical risk score. Clin Neurol Neurosurg. 2020:105792. https://doi.org/10.1016/j. clineuro.2020.105792

18. Menon S, Zhu F, Shirani A, Oger J, Freedman MS, Tremlett H. Disability progression in aggressive multiple sclerosis. Mult Scler. 2017 Mar;23(3):456-63. https://doi.org/10.1177/1352458516653273

19. Bergamaschi R, Berzuini C, Romani A, Cosi V. Predicting secondary progression in relapsing-remitting multiple sclerosis: a Bayesian analysis. J Neurol Sci. 2001 Aug;189(1-2):13-21. https://doi. org/10.1016/s0022-510x(01)00572-x

20. Simone I, Carrara D, Tortorella C, Liguori M, Lepore V, Pellegrini F, et al. Course and prognosis in early-onset MS: comparison with adult-onset forms. Neurology. 2002 Dec;59(12):1922-8. https://doi. org/10.1212/01.wnl.0000036907.37650.8e

21. Moreira M, Felipe E, Mendes M, Tilbery C. Multiple sclerosis: descriptive study of its clinical forms in 302 cases. Arq NeuroPsiquiatr. 2000 Jan;58(2B):460-6. https://doi.org/10.1590/S0004282X2000000300010

22. Koch M, Uyttenboogaart M, van Harten A, De Keyser J. Factors associated with the risk of secondary progression in multiple sclerosis. Mult Scler. 2008 Jul;14(6):799-803. https://doi. org/10.1177/1352458508089361

23. Tremlett H, Paty D, Devonshire V. Disability progression in multiple sclerosis is slower than previously reported. Neurology. 2006 Jan;66(2):172-7. https://doi.org/10.1212/01.wnl.0000194259.90286. $\mathrm{fe}$

24. Scalfari A, Neuhaus A, Daumer M, Ebers G, Muraro P. Age and disability accumulation in multiple sclerosis. Neurology. 2011 Sep;77(13):1246-52. https://doi.org/10.1212/ WNL.0b013e318230a17d

25. Trojano M, Avolio C, Manzari C, Calo A, De Robertis F, Serio G, et al. Multivariate analysis of predictive factors of multiple sclerosis course with a validated method to assess clinical events. $J$ Neurol Neurosurg Psychiatry. 1995 Mar;58(3):300-6. https://doi. org/10.1136/jnnp.58.3.300

26. Debouverie M, Pittion-Vouyovitch S, Louis S, Guillemin F, Group L. Natural history of multiple sclerosis in a population-based cohort. Eur J Neurol. 2008 Sep;15(9):916-21. https://doi.org/10.1111/j.14681331.2008.02241.x

27. Scalfari A, Neuhaus A, Degenhardt A, Rice GP, Muraro PA, Daumer $M$, et al. The natural history of multiple sclerosis: a geographically based study 10: relapses and long-term disability. Brain. 2010 Jul;133(7):1914-29. https://doi.org/10.1093/brain/awq118

28. Tremlett H, Yousefi M, Devonshire V, Rieckmann P, Zhao Y. Impact of multiple sclerosis relapses on progression diminishes with time. Neurology. 2009 Nov;73(20):1616-23. https://doi.org/10.1212/ WNL.0b013e3181c1e44f

29. Shirani A, Zhao Y, Karim ME, Evans C, Kingwell E, van der Kop ML, et al. Association between use of interferon beta and progression of disability in patients with relapsing-remitting multiple sclerosis. JAMA. 2012 Jul;308(3):247-56. https://doi.org/10.1001/jama.2012.7 
30. Trojano M, Pellegrini F, Fuiani A, Paolicelli D, Zipoli V, Zimatore GB, et al. New natural history of interferon- $\beta$-treated relapsing multiple sclerosis. Ann Neurol. 2007 Apr;61(4):300-6. https://doi.org/10.1002/ana.21102

31. Lorscheider J, Jokubaitis VG, Spelman T, Izquierdo G, Lugaresi A, Havrdova E, et al. Anti-inflammatory disease-modifying treatment and short-term disability progression in SPMS. Neurology. 2017 Sep;89(10):1050-9. https://doi.org/10.1212/WNL.0000000000004330

32. Trojano M, Paolicelli D, Tortorella C, laffaldano P, Lucchese G, Di Renzo V, et al. Natural history of multiple sclerosis: have available therapies impacted long-term prognosis? Neurol Clin. 2011 May;29(2):309-21. https://doi.org/10.1016/j.ncl.2010.12.008

33. Brown M, Kirby S, Skedgel C, Fisk J, Murray T, Bhan V, et al. How effective are disease-modifying drugs in delaying progression in relapsing-onset MS? Neurology. 2007 Oct;69(15):1498-507. https:// doi.org/10.1212/01.wnl.0000271884.11129.f3

34. Brown JWL, Coles A, Horakova D, Havrdova E, Izquierdo G, Prat A, et al. Association of initial disease-modifying therapy with later conversion to secondary progressive multiple sclerosis. JAMA. 2019 Jan;321(2):175-87. https://doi.org/10.1001/jama.2018.20588

35. Drulovic J, Ivanovic J, Mesaros S, Martinovic V, Kisic-Tepavcevic D, Dujmovic I, et al. Long-term disability outcomes in relapsingremitting multiple sclerosis: a 10-year follow-up study. Neurol Sci.
2019 Aug;40(8):1627-36. https://doi.org/10.1007/s10072-019$03878-4$

36. Jokubaitis VG, Spelman T, Kalincik T, Izquierdo G, Grand'Maison $F$, Duquette $P$, et al. Predictors of disability worsening in clinically isolated syndrome. Ann Clin Transl Neurol. 2015 May;2(5):479-91. https://doi.org/10.1002/acn3.187

37. Healy BC, Ali EN, Guttmann CR, Chitnis T, Glanz BI, Buckle G, et al. Smoking and disease progression in multiple sclerosis. Arch Neurol. 2009 Jul;66(7):858-64. https://doi.org/10.1001/archneurol.2009.122

38. Marrie RA, Cutter G, Tyry T, Campagnolo D, Vollmer T. Smoking status over two years in patients with multiple sclerosis. Neuroepidemiology. 2009;32(1):72-9. https://doi. org/10.1159/000170910

39. Pittas F, Ponsonby AL, van der Mei IA, Taylor BV, Blizzard L, Groom $\mathrm{P}$, et al. Smoking is associated with progressive disease course and increased progression in clinical disability in a prospective cohort of people with multiple sclerosis. J Neurol. 2009 Apr;256(4):577-85. https://doi.org/10.1007/s00415-009-0120-2

40. Sharafutdinova LR, Magzhanov RV, Rakhmatullin AR, Bakhtiiarova $K Z$. [Smoking as a risk factor of development and progression of multiple sclerosis (a review and experimental data)]. Zh Nevrol Psikhiatr Im S S Korsakova. 2013;113(10 Pt 2):18-22. 